\title{
URGENSI IJTIHAD EKONOMI PADA ERA GLOBALISASI
}

\author{
Amir Mu'allim dan M.Roem Syibly \\ Pusat Studi Hukum Islam, Pascasarjana FIAl-UII, Yogyakarta \\ Email: pshiuii@yahoo.com
}

\begin{abstract}
Globalization has changed the fabric of human life and lead to accelerated economic development. Islam as a religion rahmatan Iil alamin is required to always be ready to provide solutions to various issues, because not every economic problem in the modern era has been arranged in al-Quran and al-Hadith, then opened the door of ijtihad. Method of economic ijtihad has very important position, because products of globalization are very fast and diverse. The classical scholars have provided a good example of how diligence in the economic field that should be followed by the scientists of this modern era. In the çurrent era, the most appropriate economic ijtihad is the collective ijtihad as has been done by the DSN-MUI, Bahsul Masail NU, and Majelis Tarjih Muhammadiyah. However, should also noted how economic ijtihad products that now exist can be mutually reinforcing and contribute to the repertoire of minimal economic sciences of Islam, not the other way would lead to disunity.
\end{abstract}

Keywords: Economic ljtihad, Islamic economics, globalization, maslahah.

\section{PENDAHULUAN}

Laju perkembangan sains dan teknologi modern pada era globalisasi telah menimbulkan dampak besar terhadap kehidupan manusia, termasuk terhadap kegiatan ekonomi bisnis. Bentuk-bentuk bisnis dan isu-isu baru berkembanig dengan cepat, seperti hedging, sekuritisasi, money market, capital market, investasi emas, jual beli valuta asing, tata cara perdagangan melalui e-commerce, bursa komoditi, index trading (ta'amul bil mu'syar), sistem pembayaran dan pinjaman dengan kartu kredit, ekspor impor dengan media L/C, dan sebagainya.

Demikian pula perkembangan lembaga-lembaga perbankan dan keuangan mengalami kemajuan yang sangat pesat, seperti perbankan, leasing (multifinance), mutual fund, sampai kepada instrumen pengendalian moneter oleh bank sentral, exchange rate, waqf saham, MLM, jaminan fiducia dalam pembiayaan, jaminan resi gudang, dan sebagainya. Produk-produk perbankan syariah juga harus dikembangkan secara inovatif, agar bisa memenuhi kebutuhan pasar. Semua ini menjadj tantangan bagi pakar syariah.

Oleh karena perubahan sosial dalam bidang muamalah terus berkembang cepat, akibat dari akselerasi globalisasi, maka pengajaran fiqh muamalah tidak cukup secara a priori bersandar (merujuk) pada kitab-kitab klasik semata, karena formulasi fiqh muamalah masa lampau sudah banyak yang mengalami irrelevansi dengan konteks kekinian. Rumusan-rumusan fiqh muamalah tersebut harus diformulasi kembali agar bisa menjawab segala problem dan kebutuhan ekonomi modern (Agustianto, 2011).

Kondisi di atas masih didukung, didorong dan dikembangkan dalam lingkungan pasar bebas yang sudah menjadi keniscayaan dari globalisasi. Sekitar dua dasawarsa belakangan ini, kecenderungan untuk mewujudkan pasar bebas (free market) semakin kuat. Kecenderungan itu akan diwujudkan pada tingkat international dan tingkat regional. Di peringkat international terlihat pada persetujuan GATT (General Agreement on Tariff and Trade), serta terbentuknya WTO (World Trade Organization). Di peringkat regional bisa dilihat dari makin menguatnya kerjasama ekonomi dalam kawasan tertentu seperti Uni Eropa, AFTA, NAFTA, APEC dan terakhir CAFTA. 
Tujuan pasar bebas secara selintas memang positif, yakni agar perekonomian suatu negara bisa lebih maju dan berkembang. Berbagai studi memperlihatkan bahwa perdagangan dunia akan. meningkat dengan berlakunya sistem pasar bebas. Peningkatan volume perdagangan berarti peningkatan produksi, yang berarti pula peningkatan lapangan kerja dan pada akhirnya peningkatan pendapatan dan kesejateraan (Agustianto, 2011).

Salah satu kesibukan para intelektual muslim pada sistem pasar bebas di seluruh dunia kemudian ialah memikirkan bagaimana menerjemahkan nilai-nilai Islam ke dalam perangkat nyata kehidupan modern yang terus berubah ini. Seorang muslim yang serius tentu menyadari, betapa ia dihadapkan pada tantangan hidup dalam suatu masyarakat modern, yaitu suatu masyarakat yang notabene merupakan kelanjutan logis, meskipun melalui proses transmutasi yang amat besar, dari berbagai unsur tatanan dan nilai hidup yang telah pernah berkembang sebelumnya, khusus di dunia Islam (Madjid, $\mathrm{tt}_{\text {.) }}$.

Globalisasi yang menjadi ciri khas pasar bebas diperkirakan semakin bertambah cepat pada masa mendatang, sebagaimana dikemukakan oleh Colin Rose (1997), bahwa dunia sedang berubah dengan kecepatan langkah yang belum pernah terjadi sebelumnya. Kehidupan masyarakat termasuk kehidupan hukum dan ekonominya menjadi semakin kompleks (Rose dan Nicholl, 1997: 1).

Secara prinsip, globalisasi merupakan sebuah proses 'penyatuan' dunia, yang secara perlahan, tetapi pasti mulai menghilangkan sekat-sekat negara dan bangsa. Proses penyatuan ini melibatkan manusia, informasi, perdagangan, dan modal. Derasnya arus informasi yang masuk lintas benua telah menghilangkan halangan-halangan yang diakibatkan oleh batasbatas dimensi ruang dan waktu. Oleh karenanya, suatu peristiwa yang terjadi di belahan bumi akan segera bisa diketahui di belahan bumi lainnya (lihat Khotimah, 2009: 114-132).

Globalisasi, diantaranya ditandai dengan adanya fenomena penting dalam bidang ekonomi. Kegiatan ekonomi dunia tidak hanya dibatasi oleh faktor batas geografi, bahasa, budaya dan ideologi, akan tetapi lebih karena faktor saling membutuhkan dan saling bergantung satu sama lain (Pronk, 2001: 43). Globalisasi pada aspek ekonomi menurut John Naisbitt dan Patricia Aburdence ditandai dengan tiga pernyataan: (a) kekuatan-kekuatan ekonomi dunia telah melintas batas ikatan-ikatan nasional, mengakibatkan pada demokrasi yang lebih, kebebasan yang lebih, kesempatan yang lebih, dan kesejahteraan yang lebih besar, (b) pada ekonomi global, pertimbangan-pertimbangan ekonomi hampir selalu berkaitan dengan pertimbangan-pertimbangan politis, dan (c) pada ekonomi global, presiden, perdana menteri, dan parlemen akan semakin tidak berguna.

Secara jelas, adanya globalisasi ekonomi ini ditandai oleh semangat perdagangan bebas (free trade) lintas negara di dunia. Untuk hal ini, umumnya telah dibuat kesepakatankesepakatan antarnegara yang menuju arah tersebut. Di Eropa, misalnya, sejak tahun 1992 telahdiberlakukan mata uang euro yang menandai mulainya era pasar bebas antar-12 negara Eropa. Demikian juga di Amerika dan Kanada yang telah memulai hal yang sama pada tahun 1988 (lihat Khotimah, 2009: 114-132).

\section{KEBUTUHAN IJTIHAD ERA MODERN}

Dalam era globalisasi, umat Islam dihadapkan pada tantangan untuk menjawab pertanyaan tentang di mana posisi Islam dalam kehidupan modern, serta bentuk Islam yang bagaimana yang harus ditampilkan dalam menghadapi modernisasi (Tibi, 1991: 8). Yusuf alQardhawi (1994), menyatakan bahwa setelah tertutupnya pintu iftihad, pada awal abad ke19 muncul di kalangan pemikir muslim untuk membuka kembali aktivitas berijtihad dengan melakukan pembaruan hukum Islam, yang dalam masalah ijthad kontemporer ini, terdapat tiga 
pendapat. Pertama, pendapat yang mènolakijtihad dengan alasan bahwa produkulama mujtahid dan salaf telah mampu menjawab setiap tantangan zaman dan permasalahan kontemporer dewasa ini (al-Qardlawi, 1994: v). Kedua, pendapat yang menginginkan pembaruan hukum Islam secara menyeluruh dengan membuka pintu ijthad secara bebas, yang terkadang dalam ijtihad ini merekà melakukannya tanpa berpedoman atau menyalahi kode etik ijtihad yang ada. Ketiga, pendapat yang menyatakan bahwa pintu ijtihad masih terbuka tetapi tetap dengan berpedoman pada metodologi ijtihad yang telah ditentukan ulama ushul (Zein, 1997: 153155).

Tentu jika memilih opsi pertama diatas dengan terus menerus berpegang kepada pendapat ulama terdahulu, memandang hasil ijtihad mereka, adalah ijtihad yang tidak boleh diusik-usik sedikit juga, tentulah golongan ini menghendaki keislaman itu berangsur-angsur hilang dalam masyarakat (As-Shiddiqy, 1997: 551).

Dewasa ini, yang diperlukan adalah opsi yang memandang pintu ijtihad terbuka dan tetap terbuka, para ulama Islam dituntut untuk melakukan upaya rekonstruksi terhadap khasanah hukum Islam secara inovatif. Termasuk yang cukup urgen, adalah upaya para ulama tersebut untuk secara terus menerus melakukan ijtihad dibidang fiqih secara benar dan dapat dipertanggung-jawabkan. Sebab kajian soal ijtihad akan selalu mengingat kedudukan dan fungsi ijtihad dalam yurisprudensi Islam yang tidak bisa dipisahkan produk-produk fiqih, apakah itu berfungsi sebagai purifikasi atau reaktualisasi (Al-Qardawi, 2000: 5).

Dengan demikian, pada zaman modern inilah ijtihad paling dibutuhkan sebab berubahnya keadaan kehidupan setelah adanya revolusi teknologi, maka merupakan keharusan untuk membuka kembali pintu ijtihad yang memang sebenarnya tidak pernah ditutup. ljtihad zaman modern haruslah mengarah kepada masalah-masalah yang baru dan problematika kekinian, untuk mencari solusi masalah tersebut menurut al-Qur'an dan sunnah. Layak kiranya untuk meninjau kembali ijtihad zaman dahulu, agar ijtihad tersebut dapat layak kembali di zaman sekarang, atau setidak-tidaknya ijtihad tersebut tidak menganggur sia-sia, menurut porsi problematika kekinian. jjtihad yang didengung-dengungkan ada zaman sekarang ini adalah merupakan kebutuhan bahkan merupakan kewajiban bagi kehidupan umat islam untuk mengobati problematika kekinian sebab umat Islam akan hidup jumud kalau tidak diberantas dengan ijtihad (Ameen, tt).

Perubahan tata dunia yang begitu cepat mengharuskan perkembangan ekonomi Islam untuk menyesuaikan diri, ikut berpartisipasi, terlibat, mewarnai dan alih-alih memberikan alternatif pada tata laksana ekonomi dunia dengan tetap berprinsipkan ajaran-ajaran Islam. Oleh sebab itu, ijtihad bidang ekonomi menjadi sebuah kebutuhan yang terus didorong baik di bidang keuangan, industri perbankan, e-commerce, bursa komoditas, dan lain sebagainya. Perdebatan pintu ijtihad tetap terbuka atau telah tertutup sudah harus disudahi, perkembangan ekonomi yang begitu cepat sangat memerlukan landasan-landasan hukum yang jelas, oleh sebab itu, ijthad menjadi keharusan pada era modern ini.

\section{TINJAUAN UMUM TENTANG IJTIHAD}

\section{Pengertian ljtihad}

ljtihad secara bahasa terambil dari kata al-Jahdu dan al-Juhd yang artinya kekuatan, kemampuan, usaha sungguh-sungguh, kesukaran, kuasa dan daya (Yunus, 1990: 92-93 juga lihat Munawwir, 1997: 217). Kata ijtihad mempunyai makna khusus dalam Islam, yaitu pencurahan segala kemampuan secara maksimal untuk memperoleh suatu hukum syarak yang amali melalui penggunaan sumber syarak yang diakui (Al-Amidi, 1967: 204). ljtihad dalam arti luas adalah mengarahkan segala kemampuan dan usaha untuk mencapai sesuatu yang diharapkan (Djazuli, 2005: 71). 
Para ulama mendefinisikan ijtihad sebagai usaha dan upaya sungguh-sungguh seseorang (beberapa orang) ulama yang memiliki syarat-syarat tertentu, untuk merumuskan kepastian atau penilaian hukum mengenai sesuatu (atau beberapa) perkara, yang tidak terdapat kepastian hukumnya secara eksplisit dan tegas baik dalam al-Qur'an maupun dalam al-Hadis (Manan, 2006: 162-163)

ljtihad menurut ulama Ushul Figh ialah usaha seorang yang ahli figh yang menggunakan seluruh kemampuannya untuk menggali hukum yang bersifat amaliyah (praktis) dari dalil-dalil yang terperinci (Zahroh, 2000: 567). Sedangkan ijtihad dalam hal yang ada kaitannya dengan hukum adalah mengerahkan segala kesanggupan yang dimiliki untuk dapat meraih hukum yang mengandung nilai-nilai uluhiyah atau mengandung sebanyak mungkin nilai-nilai syari'ah (Umam dkk, 2001: 131)

Ada beberapa esensì yang menjadi syarat bagi terwujudnya ijtihad, yaitu: pertama, ijtihad merupakan upaya pencurahan kemampuan secara maksimal yang dilakukan oleh ulama; kedua, tujuan ijtihad adalah untuk mendapatkan kepastian hukum yang sifatnya zanni; ketiga, ijtihad dilakukan terhadap hukum yang sifatnya amali; keempat, dilakukan dengan melalui istinbat; kelima, obyek ijtihad hanyalah dalii-dalil yang zanni atau yang tidak ada dalilnya sama sekali (Mudzhar, 1998: 60).

\section{Dasar Hukum lịtihad}

Dasar hukum diperbolehkannyà melakukan ijtihad antara lain firman Allah Swt. Hai orang-orang yang beriman, taatilah Allah dan taatilah Rasul (nya), dan ulil amri di antara kamu. Kemudian jika kamu berlainan pendapat tentang sesuatu, Maka kembalikanlah ia kepada Allah (Al Quran) dan Rasul (sunnahnya), jika kamu behar-benar beriman kepada Allah dan hari kemudian. yang demikian itu lebih utama (bagimu) dan lebih baik akibatnya. (QS. An-Nisa ayat 59)

Dari ayat tersebut dapat dipahami kobolehan melakukan ijihad dalam suatu persoalan yang mungkin dalam fenomena kehidupan masyarakat dengan mengacu kepada aturan Allah Swt dan Rasul-Nya. Sedangkan dasar dibolehkan melakukan ijtihad berdasarkan hadits berikut: "Dari Mu'adz bin Jabal bahwasanya Rasululloh saw, ketika mengutusnya ke Yaman Bersabda: "Bagaimana kamu menetapkan hukum jika diajukan kepadamu sesuatu yang harus diputuskan, Muadz menjawab saya akan memutuskan berdasarkan kitab Allah, Rasulullah berkata:"jika kamu tidak menemukan dalam kitab Allah ? Muadz menjawab: "saya akañ memutus berdasarkan sunnah Rasulullah. Rasululloh berkata: "jika kamu tidak menemukan dalam sunnah Rasululloh, Muadz menjawab saya akan berijtihad dengan pendapatku dan dengan seluruh kemampuanku. Maka Rasulullah merasa lega dan berkata: Segala puji bagi Allah yang telah memberi taufiq kepada utusan Rasulullah (Muadz) dalam hal yang diridhoi oleh Rasulullah.

\section{Kriteria Mujahid}

Menurut Abdul Manan (2006), ijtihad tidak bisa dilakukan oleh sembarang orang. Ada beberapa kriteria kemampuan yang harus dipenuhi oleh setiap orang yang akan berijtihad: pertama, mengetahui dan memahami makna ayat-ayat hukum yang terdapat dalam alQur'an dan. al-Hadits. Kedua, mengetahui bahasa Arab. Ketiga, mengetahui metodologi qiyas dengan baik. Keempat, mengetahui nasikh dan mansukh. Kelima, mengetahui kaidah-kaidah ushul dengan baik dan dasar-dasar pemikiran yang mendasari rumusanrumusan kaidah tersebut. Keenam, mengetahui maqashid al-ahkam (Manan, 2006: 162163). Syarat-syarat yang diajukan Manan di atas seide dengan pandangan Muhammad 
Abu Zahroh (2000: 567) yang memberikan syarat-syarat tertentu bagi seorang mujtahid, antara syarat-syaratnya adalah:
a. Mengetahui Al-Quran, As-Sunnah dan bahasa Arab dengan pengetahuan yảng luas dan mendalam.
b. Mengetahui maqasid syarijah, prinsip-prinsip umum dan semangat ajaran Islam.
c. Mengetahui turuq al istitinbath Ushul Fiqh, metode menemukan hukum dan menerapkan hukum, agar hukum hasil ijtihad lebih mendekati kepada kebenaran.

d. Memiliki akhlak yang terpuji dan niat yang ikhlas dalam berijtihad.

\section{Lapangan ljtihad}

ljtihad hanya dapat dilakukan pada lapangan atau medan tertentu yaitu: pertama, dalil-dalil yang qath'i wurud-nya dhani dalalah-nya. Kedua, dalil-dalil yang dhani wurudnya qath'i dalalah-nya. Ketiga, dalil-dalil yang dhanni wurud dan dalalah-nya. Keempat, terhadap kasus-kasus yang tidak ada hukumnya (Djazuli, 2005: 71-72).

Menurut Qardawi, dalam bidang muammalah, lapangan ijtihad yang menuntut jawaban-jawaban baru ada dua bidang. yaitu: Pertama, bidang ekonomi atau keuangan, dalam bidang ini muncul sederetan bentuk-bentuk transaksi yang sifatnya tidak pernah dijumpai pada masa dahulu. Kedua, bidang ilmu pengetahuan atau kedokteran. Dalam bidang ini juga ditemukan berbagai cara kegiatan yang memerlukan kejelasan hukum (AlQardawi, tt: 126).

Perkembangan ekonomi yang sangat pesat dan mengglobal yang didukung oleh teknologi informasi telah melahirkan banyak produk ekonomi, oleh sebab itu, bidang ekonomi menuntut dasar-dasar hukum Islam yang sesuai dengan syariah.

\section{Metode ljtihad}

Pada masa sekarang ini menurut Yusuf Qardawi ijtihad dapat dilakukan melalui dua cara yaitu ijthad intiqa'i atau ijtihad tarjih dan ijtihad insya'i atau ijtihad ittida'i dan selain dua cara tersebut Alfitri menambahkan dengan ijtihad komparasi.

a. ljtihad Intiga'l atau ljtihad Tarjihi.

Yang dimaksud dengan ijtihad intiga'i atau ijtihad tarjih adalah ijtihad yang dilakukan seseorang atau sekelompok orang untuk memilih pendapat para ahli hukum terdahulu mengenai masalah-masalah tertentu, sebagaimana tertulis dalam berbagai kitab hukum Islam, kemudian menyeleksi mana yang lebih kuat dalilnya dan lebih relevan dengan kondisi masyarakat.

b. ljtihad insya'i.

Pola ijthad yang kedua yang dibutuhkan pada masa sekarang adalah jitihad insya'i. Ijthad insya'l adalah usaha untuk menetapkan kesimpulan hukum mengenai peristiwaperistiwa baru yang belum diselesaikan oleh para ahli hukum terdahulu (Al-Qardawi, $\mathrm{tt}$ : 126). Kegiatan ijthad insya'i mutlak harus kembali diaktifkan guna mencari solusi-solusi baru terhadap permasalahan yang baru muncul serta demi pengembangan hukum Islam, sebab setiap masa memiliki problem yang berbeda, demikian pula halnya dengan masa sekarang, problemnya tidak serupa dengan masa dahulu. Kriterianya sangat keras dialamatkan kepada sebagian ulama yang menganggap bahwa pintu ijtihad telah tertutup ((Al-Qardawi, tt: 19). 
Urgensi ljtihad Ekonomi Pada Era Globalisasi (Amir Mu'allim dan M. Roem Syibly)

c. ljtihad Komparatif.

ljtihad komparatif ialah mengabungkan kedua bentuk ijtihad di atas (intiqai dan isnya'i). Dengan demikian di samping untuk menguatkan atau mengkompromikan beberapa pendapat, juga diupayakan adanya pendapat baru sebagai jalan keluar yang lebih sesuai dengan tuntunan zaman. Pada dasarnya hasil ijtihad yang dihasilkan oleh ulama terdahulu merupakan karya agung tetap utuh, bukanlah menjadj patokan mutlak, melainkan masih memerlukan ijtihad baru. Karena itu, diperlukan kemampuan mereformulasi hasil sebuah ijtihad, dengan jalan menggabungkan kedua bentuk ijtihad di atas (AIFitri, tt: 12).

Teknis pengambilan keputusan dalam berijtihad pada era modern ini lebih diutamakan dan ditekankan dengan model ijtihad kolektif. Secara tekstual dan konstekstual menegaskan bahwa berkumpulnya ulil amri untuk bermusyawarah dalam menentukan hukum sebuah masalah yang tidak ada hukumnya dalam al-Qur'an maupun As-Sunnah, kemudian sampai pada pendapat yang disepakati, merupakan salah satu bentuk ijtihad dan salah satu sumber pokok hukum Islam, dan mengamalkan keputusan jamaah ketika itu lebih diutamakan daripada melaksanakan hasil ijtihad personal. Contoh ijtihad kolektif yang mashur adalah ijthad para sahabat mengenai bumi taklukan, kota jabiyah. ljtihad pada saat itu dilakukan oleh Umar bin Khattab beserta sahabat-sahabat yang lain dalam hal penyerahan tanah hasil rampasan perang.

ljtihad kolektif yang independen adalah hujjah yang mengikat semua umat sesuai dengan kaidah: "Keputusan pemerintah dalam masalah yang diperselisihkan akan mengangkat perselisihan." Kaidah ini terbatas pada masalah yang tidak bertentangan, dan berdirinya ulil amri untuk mengatur ljtihad kolektif, menjadikannya memiliki nilai praktis dan menambahkan kekuatan hukumnya (Oglu, 2011).

\section{MASHLAHAH SEBAGAI LANDASAN IJTIHAD EKONOMI}

Dalam studi prinsip ekonomi Islam, maslahah ditempatkan pada posisi kedua, yaitu sesudah prinsip tawhid. Al-Mashlahah adalah lafaz al-mamfaat artinya baik, dengan demikian al-Mashlahah al-Mursalah adalah suatu kemaslahatan yang tidak mempunyai dasar dalil, tetapi juga tidak ada pembatalanya (Syafe'i, 1999: 117). Mashlahah adalah tujuan syariah Islam dan menjadi inti utama syariah Islam itu sendiri. Para ulama merumuskan maqashid syari'ah (tujuan syariah) adalah mewujudkan kemaslahatan. Imam Al-Juwaini, Al-Ghazali, Asy-Syatibi, Ath-Thufi dan sejumlah ilmuwan Islam terkemuka, telah sepakat tentang hal itu. Dengan demikian, sangat tepat dan proporsional apabila maslahah ditempatkan sebagai prinsip kedua dalam ekonomi Islam.

Secara umum, maslahah diartikan sebagai kebaikan (kesejahteraan) dunia dan akhirat. Para ahli ushul fiqh mendefinisikannya sebagai segala sesuatu yang mengandung manfaat, kegunaan, kebaikan dan menghindarkan mudharat, kerusakan dan mafsadah. (jalb al-naf'y wa daf' al-dharar). Imam Al-Ghazali menyimpulkan, maslahah adalah upaya mewujudkan dan memelihara lima kebutuhan dasar, yakni agama, jiwa, akal, keturunan dan harta.

Penerapan maslahah dalam ekonomi Islam (muamalah) memiliki ruang lingkup yang lebih luas dibanding ibadah. Ajaran Islam tentang muamalah umumnya bersifat global, karena itu ruang ijtihad untuk bergerak lebih luas. Ekonomi Islam yang menjadi salah satu bidang muamalah berbeda dengan ibadah murni (ibadah mahdhah). Ibadah bersifat dogmatik (ta'abbudi), sehingga sedikit sekali ruang untuk berijtihad. Ruang ijtihad dalam bidang ibadah sangat sempit. Lain halnya dengan ekonomi Islam (muamalah) yang cukup terbuka bagi inovasi dan kreasi baru dalam membangun dan mengembangkan ekonomi Islam. Oleh karena itu prinsip maslahah dalam bidang muamalah menjadi acuan dan patokan penting. Apalagi bila 
menyangkut kebijakan-kebijakan ekonomi yang dikategorikan sebagai manthiqah al firagh al tasyri'y (area yang kosong dari tasyri'/hukum). Sedikitnya nash-nash yang menyinggung masalah yang terkait dengan kebijakan-kebijakan ekonomi teknis, membuka peluang yang besar untuk mengembangkan ijtihad dengan prinsip maslahah.

Kemaslahatan dalam bidang muamalah dapat ditemukan óleh akal/pemikiran manusia melalui ijtihad. Misalnya, akal manusia dapat mengetahui bahwa curang dan menipu dalam kegiatan bisnis adalah perilaku tercela. Demikian pula praktik riba. Para filosof Yunani yang hidup di zaman klasik, bisa menemukan dengan pemikirannya bahwa riba adalah perbuatan tak bermoral yang harus dihindari.

Mashlahah sebagai salah satu model pendekatan dalam ijtihad menjadi sangat vital dalam pengembangan ekonomi Islam dan siyasah iqtishadiyah (kebijakan ekonomi). Mashlahah adalah tujuan yang ingin diwujudkan oleh syariah. Mashlahah merupakan esensi dari kebijakan-kebijakan syariah (siyasah syar 'iyyah) dalam merespon dinamika sosial, politik, dan ekonomi. Maslahah `ammah (kemaslahatan umum) merupakan landasan muamalah, yaitu kemaslahatan yang dibingkai secara syar'i, bukan semata-mata profit motive dan material rentability sebagaimana dalam ekonomi konvensional (Agustianto, 2011).

\section{IJTIHAD EKONOMI ULAMA KLASIK}

ljtihad ekonomi telah banyak dilakukan oleh para ilmuwan muslim pada era klasik di antaranya adalah Ibnu Khaldun (1332-1406), Ibnu Taymiyah, Al-Ghazali (w.1111) Al-Maqrizi . Selain itu juga, masih banyak ditemukan buku-buku yang khusus membahas bagian tertentu dari ekonomi Islam, seperti, Kitab Al-Kharaj karangan Abu Yusuf (w.182 H/798 M), Kitab Al-Kharaj karangan Yahya bin Adam (.w.203 H), Kitab Al-Kharaj karangan Ahmad bin Hanbal (w.221 M), Kitab Al-Amwal karangan Abu 'Ubaid ( w.224 H ), Al-lktisab fi al Rizqi, oleh Muhammad Hasan Asy-Syabany. (w.234 H) (lkhsan. 2011).

Ibnu Khaldun misalnya, pemikir muslim yang juga sebaga bapak ekonomi dunia ini telah banyak memberikan kontribusi pemikirannya pada bidang ekonomi, termasuk ajaran tentang tata nilai, pembagian kerja, sistem harga, hukum penawaran dan permintaan, konsumsi dan produksi, uang, pembentukan modal, pertumbuhan penduduk, makro ekonomi dari pajak dan pengeluaran publik, daur perdagangan, pertanian, indusrtri dan perdagangan, hak milik dan kemakmuran, dan sebagainya. la juga membahas berbagai tahapan yang dilewati masyarakat dalam perkembangan ekonominya. Kita juga menemukan paham dasar yang menjelma dalam kurva penawaran tenaga kerja yang kemiringannya berjenjang mundur. ljtihad-ijtihad Ibnu Khaldun tesebut hingga kini tetap abadi dan bagian dari rujukan dalam pengembangan ekonomi (Shiddiqy, 1976: 261).

Demikian juga pemikiran ekonomi Ibnu Taimiyyah, misalnya tentang kompensasi dan harga yang adil, fungsi uang dan perdagangan uang, serta implikasi penerapan lebih dari satu standar mata uang, dan masih banyak lagi para pemikir muslim klasik, yang telah berjihad sebagai usaha memberikan kepastian hukum terhadap berbagai persoalan yang timbul pada saat itu.

\section{MODEL IJTIHAD EKONOMI MODERN}

Sebagaimana dijelaskan di atas, teknis pengambilan keputusan dalam berijtihad pada era modern ini lebih djutamakan dengan model ijthad kolektif, sebab dengan model ini memiliki beberapa faedah. Oglu (2011), mencatat sejumlah faedah, diantaranya:

1. Untuk merealisasikan metode penetapan hukum yang ditradisikan Rasulullah Saw dalam menghadapi persoalan baru. 
2. Mengatasi pengaruh ruang, waktu dan keadaan dalam menciptakan seorang mujtahid mutlak, baik secara kualitas maupun kuantitas dan mencegah timbulnya bahaya yang diakibatkan kelangkaan ulama dan ahli fikih yang layak menjadi mujtahid mutlak.

3. Metode kolektif dalam perundangan adalah langkah dasar terciptanya persatuan Islam

4. Melawan berbagai serangan dan tuduhan bathil

5. Melapangkan jalan untuk mengaplikasikan syariah Islam dan berhukum dengan hukum Allah

6. Kebutuhan yang sangat mendesak untuk mereformasi fikih Islam dan mengemasnya dalam bentuk modern.

7. Mencegah pembekuan ijtihad dan mengefektifkan pengaruhnya dalam menghadapi tantangan kolonialisme modern

8. ljtihad kolektif lebih detail dan valid serta lebih kuat daripada ijtihad personal

9. Keniscayaan mengambil metode kolektif dalam pensyariahan hukum untuk mengatasi problematika kontemporer.

Diantara model-model ijtihad secara kolektif dan memberikan pengaruh yang cukup besar di masyarakat Indonesia khususnya dibidang ekonomi Islam adalah fatwa Dewan Syariah Nasional, Majelis Ulama Indonesia (DSN-MUI), Bahsaul Masail NU, dan Majelis Tarjih Muhammadiyah.

Metode yang dipergunakan oleh Komisi Fatwa MUI dalam proses penetapan suatu hukum dilakukan melalui tiga pendekatan, yaitu pendekatan Nash Qath'i, pendekatan Qauli, dan pendekatan Manhaji. Pendekatan Nash Qoth'i dilakukan dengan berpegang kepada nash al-Qur'an atau Hadis untuk sesuatu masalah apabila masalah yang ditetapkan terdapat dalam nash al-Qur'an ataupun Hadis secara jelas. Sedangkan apabila tidak terdapat dalam nash alQur'an maupun Hadis maka penjawaban dilakukan dengan pendekatan Qauli dan Manhaji.

Pendekatan Qauli adalah pendekatan dalam proses penetapan fatwa dengan mendasarkannya pada pendapat para imam mazhab dalam kitab-kitab fiqih terkemuka (al-kutub al-mu'tabarah). Pendekatan Qauli dilakukan apabila jawaban dapat dicukupi oleh pendapat dalam kitab-kitab fiqih terkemuka (al-kutub al-mu'tabarah) dan hanya terdapat satu pendapat (qaul), kecuali jika pendapat (qaul) yáng ada dianggap tidak cocok lagi untuk dipegangi karena sangat sulit untuk dilaksanakan (ta'assur atau ta'adzdzur al-'amal atau shu'ubah al-'amal), atau karena alasan hukumnya ('illah) berubah. Dalam kondisi seperti ini perlu dilakukan telaah ulang (i'adatun nazhar), sebagaimana yang dilakukan oleh ulama terdahulu. Karena itu mereka tidak terpaku terhadap pendapat ulama terdahulu yang telah ada bila pendapat tersebut sudah tidak memadai lagi untuk didijadikan pedoman. Apabila jawaban permasalahan tersebut tidak dapat dicukupi oleh nash qoth'i dan juga tidak dapat dicukupi oleh pendapat yang ada dalam kitab-kitab fiqih terkemuka (al-kutub al-mu'tabarah), maka proses penetapan fatwa dilakukan melalui pendekatan manhaji.

Pendekatan Manhaji adalah pendekatan dalam proses penetapan fatwa dengan mempergunakan kaidah-kaidah pokok (al-gowaid al-ushuliyah) dan metodologi yang dikembangkan oleh imam mazhab dalam merumuskan hukum suatu masalah. Pendekatan manhaji dilakukan melalui ijtihad secara kolektif (jitihad jama'i), dengan menggunakan metoda : mempertemukan pendapat yang berbeda (al-Jam'u wat taufiq), memilih pendapat yang lebih akurat dalilnya (tarjihi), menganalogkan permasalahan yang muncul dengan permasalahan yang telah ditetapkan hukumnya dalam kitab-kitab fiqh (ilhaqi) dan istinbathi. 
Dalam masalah yang terjadi khilafiyah di kalangan imam mazhab maka penetapan fatwa didasarkan pada hasil usaha penemuan titik temu di antara pendapat-pendapat madzhab melalui metode al-Jam'u wa al-Taufiq. Jika usaha al-Jam'u wa al-Taufiq tidak berhasil maka penetapan fatwa dilakukan melalui metode tarjihi (memilih pendapat ulama yang dinilai paling kuat dalil dan argumentasinya), yaitu dengan menggunakan metode perbandingan mazhab (muqaran al-madzahib) dan dengan menggunakan kaedah-kaedah ushul fiqh perbandingan (al-Aiyub, 2009).

Metode penerapan hukum dalam fatwa DSN MUI tetap merujuk pada al-Qur'an dan al-Sunnah sebagai sumber utama serta qiyas dan ijma' sebagai metodologinya serta qaidah ushul sebagai sandaran kemaslahatannya. Dari fatwa-fatwa itu terlihat jelas mutiara-mutiara maslahah yang kental dengan prinsip-prinsip syariah antara lain:

1. Bunga /riba tidak dibenarkan

2. Mudhorobah dan wadiah dibenarkan syariah

3. Saling ridho(an-tarodhin)

4. Halal toyyib (halalan toyyiban)

5. Bebas riba dan exploitasi (Dhulm)

6. Bebas manipulasi (ghoror)

7. Saling menguntungkan (taawun)

8. Tidak Membahayakan (mudhorot)

9. Dilarang spekulasi (maysir)

10. Dilarang memonopoli dan menimbun (ihtikar).

Kemudian pada model ijtihad Majlis Tarjih dan Lajnah Bahtsul Masail sama-sama berorientasi pada jjtihad jama'i (kolektif), dengan kemungkinan tarjih yang tidak jauh berbeda, dengan mengandalkan kaidah pentarjihan yang sudah jadi. Metode penarikan kesimpulan atas persoalan hukum yang mengemuka juga tidak beda, sama-sama lebih banyak menggunakan metode tanya jawab. Keputusan hukum dari kedua lembaga tersebut sama-sama dapat dikategorikan sebagai sebuah fatwa.

Sementara itu, sebagai konsekuensi dari paradigma madzhabian NU, dalam beristinbath Lajnah Bahtsul Masail cenderung berbeda dengan Majlis Tarjih. Lajnah Bahtsul Masail menggunakan metode qauliy, ilhaqi dan manhaji. Sementara Majlis Tarjih lebih ke arah bayani, ta'lili dan istish/ahi. Lajnah Bahtsul Masail tidak mau menyebut istinbath-nya sebagai sebuah ijtihad, sedangkan Majlis Tarjih bersikukuh tidak masalah menyebut istinbath-nya sebagai ijtihad. Masalah rujukan utama dalam berijtihad, Majlis Tarjih terlihat konsisten untuk merujuk langsung pada dalil-dalil al-Quran dan Sunah. Sementara Lajnah Bahtsul Masail lebih mengandalkan pendapat imam dan ulam madzhab dalam al-kutub al-mu'tabarah. Majlis Tarjih juga tidak serigid Lajnah Bahtsul Masail dalam mengejawantahkan syarat-syarat ijtihad yang telah ditetapkan oleh para mujtahid klasik. Keputusan-keputusan hukum Majlis Tarjih lebih bersifat konseptual tematis, sementara Lajnah Bahtsul Masail lebih bersifat sederhana, kecuali keputusan-keputusan yang ditetapkan setelah tahun 1992. Sesederhana apapun keputusan Majlis Tarjih, selalu menyertakan dalil dari al-Quran dan Sunah. Sepenting apapun keputusan Lajnah Bahtsul Masail, selalu merujuk pada pendapat madzhab.

Perbedaan-perbedaan metodologi yang terdapat di dalam sistem dan metode ijtihad Majlis Tarjih dan Lajnah Bahtsul Masail adalah sebagai akibat dari perbedaan cara pandang antara Muhammadiyah dan NU, organisasi induk dari Majlis Tarjih dan Lajnah Bahtsul Masail, 
terhadap konsep agama, sistem bermadzhab, bahkan konsep tentang taqlid dan ijtihad itu sendiri (Kurdi, 2009).

Selain tiga lembaga tersebut diatas, jititiad ekonomi juga dilakukan oleh pemerintah lewat lembaga resmi perbankan, Bank Indonesia $(\mathrm{Bl})$ misalnya. Bl telah banyak mengeluarkan peraturan-peraturan yang berkaitan dengan perbankan syari'ah.

\section{PENUTUP}

Setelah diketahui bahwa ijtihad adalah merupakan kewajiban bagi umat Islam, apakah pantas bagi umat Islam untuk meninggalkannya dengan alasan terlalu banyaknya sarat yang mustahil disanggupi oleh seseorang, sebenarnya syarat tersebut adalah bukan untuk menyulitkan umat Islam seperti yang diungkapkan oleh orang yang dengan sengaja menutup pintu ijtihad. Rasyid Ridla dalam tafsir al Mannar berkata: litihad adalah bukan merupakan hal yang sulit dan tidak membutuhkan sesuatu yang merèpotkan dan menyulitkan seperti orangorang yang ingin mendapatkan gelar ilmu yang tinggi dalam ilmu kedokteran, falsafah atau yang lainnya. Begitu juga di ungkapkan oleh ibnu Arafah yang dinukil oleh Ubay dalam syarah muslim; "Ketahuilah ijtihad zaman sekarang lebih mudah dibandingkan ijtihad zaman dahulu sebab banyaknya usaha-usaha untuk menyetak buku dan menerbitkannya, dan banyaknya buku yang menerangkan secara husus tentang ijtihad. Kalau dibandingkan ijtihad ulama zaman dahulu yang banyak memakan waktu untuk memecahkan satu masalah, tetapi setelah adanya percetakan (sekitar $13 \mathrm{H}$ ) menjadi mudahlah segala sesuatu yang dahulunya sulit". Ibrahim bek juga mengatakan bahwa ijtihad zaman sekarang lebih mudah dikarenakan sekarang telah banyak karangan-karangan yang mempunyai bobot baik dalam ilmu tafsir atau yang lainnya, banyaknya syarah-syarah hadist, juga berkat adanya kamus-kamus dan kitab husus tentang ayat ahkam dan lain sebagainya (Ameen, $\mathrm{tt}$ ).

Dewasa ini dunia Islam sudah sangiat memerlukukan adanya mujtahid dan mujaddid yang profesional. Sebab, kehidupan masyarakat telah diwarnai dengan inovasi di segala bidang, sedangkan nash-nash al-Quran dan al-Hadis tidak menerangkan segala persoalan secara tekstual. Dalam keadaan seperti itu, sangat dibutuhkan pemikiran yang bersih dan penuh kesungguhan untuk mengembalikan tatanan kehidupan yang sesuai dengan prinsip dasar ajaran Islam (Al-Fitri, tt: 12).

MUI, NU, Muhammadiyah, Persis, dan banyak lagi ormas-ormas Islam yang lain, juga pemerintah musti secara cepat memberikan ijtihad-ijtihad ekonomi sehubungan dengan cepatnya perkembangan ekonomi global yäng secara alamiah selalu melahirkan produkproduk baru, sehingga Islam sebagai agama rahmatan lil 'alamin selalu siap sedia memberikan jawaban atas persoalan-persoalan di masyarakat, sebab Islam sangat identik dengan hukum dan hukum itu sendiri (Islam is the law) (lihat Minhaji, 2000: 243).

Namun demikian, para ulama yang terlibat dalam kerja-kerja ijtihad tidak semata-mata mempertimbangkan kaidah-kaidah ushuliah, kaidah istimbat hukum, tetapi juga pertimbangan kondisi sosial masyarakat, sehingga persoalan hukum seiring dengan kondisi masyarakat. Sering sekali perbedaan metodologi yang dilakukan akan mengahasilkan produk ijthad yang berbeda, oleh sebab itu, perlu juga difikirkan bagaimana perbedaan hasil ijtihad tidak menimbulkan keresahan dan perpecahan umat. 
UNISIA, Vol. XXXIII No. 75 Juli 2011

\section{DAFTAR PUSTAKA}

Agustianto (2011) "Pasar Bebas dan Ekonomi Kerakyatan", dalam http://www.agustiantocentre: com, dikutip pada 15 April 2012.

Agustianto (2011) "Reformulasi Fikih Muamalah di Ėra Modern", dalam http://www. agustiantocentre.com, dikutip pada 15 April 2012.

Agustianto (2011) "Urgensi Maslahah dalam ljtihad Ekonomi Islam", dikutip dari http://www. agustiantocentre.com, pada 21 Maret 2012.

al Aiyub, Sholahudin (2009) "Bagaimana Metode Penetapan Fatwa di MUI?", dalam http:// www.mui.or.id

Al Fitri ( (tt) Kebutuhan ljtihad Pada Zaman Moderen dan Bentuknya.

Al-Amidi (1967) al-lhkam fi Usul al-Ahkam, juz 3. Cairo: Muaśsasah al-Halabi.

Al-Qardawi, Yusuf (tt) Al-ijtihad al-Muajir.

Al-Qardawi, Yusuf (2000) litihad Kontemporer; Kode Etik dan Berbagai Penyimpangan, Cet. I. Surabaya: Risalah Gusti.

al-Qardlawi, Yusuf (1994) al-litihâd al-Mu'âshir baina al-Inzhibâth wa al-Infirâth. Kairo: Dar al-Tauzi' wa al-Nasyr al-Islamiyyah.

Ameen, Husnul Aqib (tt) "ljtihad Kontemporer, Problem dan Solusinya", dalam KMNU Online, dikutip pada 17 April 2012.

As-Shiddiqy, TM. Hasbi (1997) Pengantar Hukum Islam, Cet. I Edisi Il. Semarang: PT. Pustaka Riski Putra.

Djazuli, A. (2005) Ilmu Fìq Peenggalian, Perkembangan dan Penerapan Hukum Islam. Jakarta: Kencana Prenada Media Grouf.

Ikhsan, (2011) "Sejarah pemikiran ekonomi Al-ghazali, Ibnu Taimiyah dan Nizam Al-Mulk", dalam www.ikhsan-blogspot.com

Khotimah, Khusnul (2009) "Islam dan Globalisasi, Sebuah Pandangan tentang Universalitas Islam", dalam Junal Komunika Vol.3 No.1 Januari-Juni 2009.

Kurdi, Muhammad (2009) "Metodologi ljtihad Muhammadiyah dan NU: Studi Perbandingan Majlis Tarjih Dan Lajnah Bahtsul Masail". Malang: Skripsi Syari'ah, UMM.

Madjid, Nurcholish (tt) Pandangan Kontemporer Tentang Fiqh, Telaah Problematika Hukum Islam di Zaman Modern, dalam Budhy Munawar-Rachman (ed). Kontekstualisasi Doktrin Islam dalam Sejarah. Jakarta: Penerbit Yayasan Paramadina.

Manan, Abdul (2006) Reformasi Hukum Islam di Indonesia. Jakarta: PT Raja Grafindo Persada.

Minhaji (2000) Supremasi Hukum dalam Masyarakat Madani, dalam "Islam dan Politik" Jurnal UNISIA No. 41/XXII/IV/2000. 
Urgensi ljtihad Ekonomi Pada Era Globalisasi (Amir Mu'allim dan M. Roem Syibly)

Mudzhar, Athó (1998) Membaca Gelombang ljtihad: Antara Tradisi dan Liberasi. Yogyakarta: Titian llahi Press.

Munawwir, A.W. (1997) Kamus al-Munawwir Arab-Indonesia Terlengkap, cet.25. Jakarta: Pustaka Progressif.

Oglu, Yasar Sharif Damad (2011) "Ijtihad kolektif, Keniscayaan Modernitas dan Kewajiban Agama (2)", dalam takrib.info/indonesia.

Pronk, Jan. (2001) "Globalization: A Developmental Approach", dalam Jan Nederveen Pieterse (ed.), Global Futures, Shaping Globalization, London: Zed Books.

Rose, Collin dan Malcolm J. Nicholl (1997) Accelerated Learning for the 21 st Century. New York: Delacorte Press.

Syafe'i, Rachmat (1999) Ushul Fiqih, cet I. Bandung; CV. Pustaka Setia.

Tibi, Bassam (1991) Islam and the Cultural Accomodation of Social Change. Oxford: Westview Press.

Umam, Khairul, et.al. (2001) Ushul Fiqih II, cet. II. Bandung: CV. Pustaka Setia.

Yunus, Mahmud (1990) Kamus Arab-Indonesia, cet. 8. Jakarta: Hidakarya Agung.

Zahroh, Muhàmmad Abu (2000) Ushul al Fiqh, alih bahasa Sefullah Ma'shum, dkk, Jakarta: Pustaka Firdaus.

Zein, Satria Effendi M. (1997) 70 Tahun K.H. Ali Yafie. Bandung: Mizan. 